\title{
Exploring the role of instrument design and instrument interaction for eco-innovation: a survey-based analysis of renewable energy innovation in Germany
}

Karoline S. Rogge ${ }^{a b *}$ and Joachim Schleich ${ }^{b c d}$

\author{
a - SPRU - Science Policy Research Unit, University of Sussex, Brighton, UK \\ $b$ - Fraunhofer Institute for Systems and Innovation Research ISI, Karlsruhe, Germany \\ c - Grenoble Ecole de Management, Grenoble, France \\ $d$ - Virginia Polytechnic Institute \& State University, Blacksburg, VA, USA \\ * - Corresponding author: k.rogge@sussex.ac.uk
}

\begin{abstract}
Empirical research on eco-innovation has produced a substantive body of literature on the relevance of regulation for stimulating such innovation. Much of this work on the role of policy for eco-innovation relies on econometric analyses of company survey data. In this regard, the eco-innovation module introduced in 2008/9 in the Community Innovation Survey serves as an important data source that has helped improve our understanding of the role of environmental and innovation policy for eco-innovation in the European Union (EU). However, so far, this data source has provided only limited opportunities to generate insights into the role of instrument design and instrument interaction for ecoinnovation. In this chapter, we present a first attempt to measure such aspects in a company innovation survey based on the example of renewable energy innovation in Germany. In particular, we explore to what extent the design of the German Renewable Energy Sources Act (and the interaction of its feed-in tariffs with the EU emissions trading system) correlates with innovation in renewable power generation technologies. We find instrument design features but not instrument type to be related to eco-innovation. In addition, our exploratory study provides evidence for an interaction effect between climate policy and renewables support policy. Based on these findings, we discuss implications for future research on the role of policy in eco-innovation.
\end{abstract}

Keywords: Eco-innovation, instrument design features, instrument interaction, renewable energy, sustainability transition, policy mix, decarbonization 
Rogge K.S. and Schleich J. (2018): Exploring the Role of Instrument Design and Instrument Interaction for Eco-Innovation: A Survey-Based Analysis of Renewable Energy Innovation in Germany. Chapter 11, pp 233-256, in: Horbach J. and Reif C. (eds): New Developments in Eco-Innovation Research. Sustainability and Innovation. Springer, Cham.

https://doi.org/10.1007/978-3-319-93019-0 11.

\section{Introduction}

Addressing the various environmental sustainability challenges associated with issues such as climate change, biodiversity loss, or resource constraints requires the redirection and acceleration of innovation towards sustainable solutions. 1 The prevalence of various market, structural and transformational system failures that hinder eco-innovation and wider sustainability transitions (Weber and Rohracher, 2012) has led to an emerging literature acknowledging the need for policy intervention in the form of policy mixes (OECD, 2015; Rogge and Reichardt, 2016). Large discrepancies remain, however, between this acknowledgement and the mainstreaming of such thinking into innovation policy and research (OECD/IEA/NEA/ITF, 2015; Rogge et al., 2017).

For such an endeavor, much can be learned from the literature on eco-innovation, which has long recognized the important role of policy in spurring such innovation (Rennings, 2000; Jaffe et al., 2002; OECD, 2011). Building on the notion of "double externalities", past empirical research has provided important insights into the measurement and determinants of eco-innovation (del Río, 2009; OECD, 2009; Kemp and Pontoglio, 2011; Bergek and Berggren, 2014). One of the key policy insights of this literature is that ecoinnovation depends more on the design than on the type of a policy instrument (Kemp, 1997; Vollebergh, 2007), with environmental stringency standing out as a particularly relevant design feature (Frondel et al., 2008; Ghisetti and Pontoni, 2015).

Important insights have been gained into the role of instrument mixes for eco-innovation. Most prominently, studies conclude that combining demand-pull and technology-push instruments (Peters et al., 2012; Costantini et al., 2015, Schleich et al., 2017) is conducive to eco-innovation. In addition, research has stressed the importance of employing systemic instruments (Taylor, 2008; Wieczorek and Hekkert, 2012). However, most of the literature exploring instrument interactions and the role of design features for such interactions assumes an ex-ante perspective (Spyridaki and Flamos, 2014; del Río and Cerdá, 2017). Only a few studies to date have employed an ex-post perspective (Guerzoni and Raiteri, 2015; Cantner et al., 2016).

A recent review of econometric survey-based analyses shows that regulation is one of the few generally statistically significant determinants of eco-innovation (del Río et al.,

1 This chapter draws in parts on earlier work published by the authors as Rogge and Schleich (2018) (and the corresponding working paper Rogge and Schleich, 2017), but the focus of our analysis here differs: Whereas this earlier work examines the impact of policy mix characteristics on green innovation, here we focus on the relevance of instrument design and instrument interaction. 
Rogge K.S. and Schleich J. (2018): Exploring the Role of Instrument Design and Instrument Interaction for Eco-Innovation: A Survey-Based Analysis of Renewable Energy Innovation in Germany. Chapter 11, pp 233-256, in: Horbach J. and Reif C. (eds): New Developments in Eco-Innovation Research. Sustainability and Innovation. Springer, Cham.

\section{https://doi.org/10.1007/978-3-319-93019-0 11.}

2016). Because of data limitations, however, econometric models typically capture the effect of a particular policy instrument by including a dummy variable (del Río et al., 2016). In contrast, some specialized eco-innovation surveys have provided more indepth insights into the link between policy and eco-innovation by including environmental policy stringency as a policy variable, for instance (Johnstone, 2007; Kammerer, 2009). Others have considered climate, energy and innovation policy instruments simultaneously (Schmidt et al., 2012), but have not allowed for their interaction.

Despite recent progress in gathering more detailed policy data alongside other innovation measures, to the best of our knowledge, survey-based analyses have not yet simultaneously looked at instruments, their design and their interaction. Especially large-scale innovation surveys, such as the Community Innovation Survey (CIS) conducted within the European Union, tend to cover policy to a limited extent, and often have a narrow focus on public support for research and development (R\&D), appropriation methods, or obstacles to innovation. Similarly, the Oslo Manual, which provides guidelines for innovation surveys, puts little emphasis on the measurement of policy instruments, their design and interaction as a determinant of innovation, despite stressing the important role of innovation survey data for guiding policy (OECD, 2005).

A notable exception to this apparent neglect of policy in mainstream innovation surveys is the question block on eco-innovation, which was introduced as a supplement to the $2008 \mathrm{CIS}$ wave, following suggestions made by the 'Measuring Eco-Innovation' (MEI) project (Kemp and Pearson, 2007). Since then, these large-scale surveys have collected and analyzed information on eco-innovation and its drivers that explicitly includes (environmental) policy for the participating countries such as Germany, Spain, Italy and France. Using the CIS survey as a key data source allowed a better understanding of the factors related to eco-innovation in general, and the role of policy in particular (Rennings and Rammer, 2011; Horbach et al., 2013; Borghesi et al., 2015). However, these studies have not focused on the role of instrument design and instrument interaction for eco-innovation.

In this paper, we take a first step towards addressing this current shortcoming based on the example of the decarbonization of the energy system, in which renewable energies play a key role (Jacobsson and Bergek, 2004; Gallagher et al., 2012). Given that innovation in the energy sector is dominated by suppliers, we focus on the manufacturers of renewable power generation technologies (Pavitt, 1984; Rogge and Hoffmann, 2010). We limit the scope of our explorative study to the German Energiewende because of its pioneering role in renewable energy policy and innovation (Bruns et al., 2011; Pegels and Lütkenhorst, 2014; Strunz, 2014; Quitzow et al., 2016). 
Building on a recent study examining the impact of policy mix characteristics on innovation (Rogge and Schleich, 2018), this chapter aims to empirically explore the role of policy instrument design (e.g. regarding the level of support) and instrument interactions using data from a survey among manufacturers of renewable energy technologies. In particular, we are interested in answering the question of whether innovation in these technologies is related to respondents' perceptions about the EU emissions trading system (EU ETS), the (design of the) German Renewable Energy Sources Act (EEG) and the interaction between them. We have chosen the EU ETS and the EEG as the two core demand-pull instruments for our analysis. This is in line with the wider literature on instrument interaction, which has largely focused on interactions between climate policies and renewable energy policies (IEA, 2011; Gawel et al., 2014; Spyridaki and Flamos, 2014). Our empirical analysis relies on data collected using a redesigned CIS questionnaire, which explicitly captures the current policy mix and innovation in renewable power generation technologies. The resulting unique dataset collected in 2014 allows us to econometrically analyze the links between the instrument mix and eco-innovation.

The remainder of the chapter is structured as follows. In Section 2, we develop our analytical framework from the literature. Section 3 presents the research case of the German Energiewende, and Section 4 introduces our methodological approach. In Section 5, we present our results, and discuss these in Section 6 and offer concluding remarks.

\section{$2 \quad$ Analytical framework}

In line with the eco-innovation literature, our interdisciplinary analytical framework as presented in Figure 1 differentiates between firm-external and firm-internal determinants of eco-innovation (del Río, 2009). This framework draws on environmental economics, innovation studies and policy analysis and builds on earlier work by the authors (Rogge and Schleich, 2018). However, here we introduce a new focus on multiple instruments and their interactions, thereby contributing to policy mix studies focusing on instrument interactions (del Río, 2006; Spyridaki and Flamos, 2014). 
Rogge K.S. and Schleich J. (2018): Exploring the Role of Instrument Design and Instrument Interaction for Eco-Innovation: A Survey-Based Analysis of Renewable Energy Innovation in Germany. Chapter 11, pp 233-256, in: Horbach J. and Reif C. (eds): New Developments in Eco-Innovation Research. Sustainability and Innovation. Springer, Cham.

https://doi.org/10.1007/978-3-319-93019-0 11.

Figure 1: Analytical framework for exploring the determinants of eco-innovation

\begin{tabular}{|l|l|}
\hline \multicolumn{2}{|l|}{$\begin{array}{l}\text { Technology push } \\
\text { - Public R\&D funding }\end{array}$} \\
Market demand & \\
- Global demand pull & \\
Instrument mix & $\begin{array}{l}\text { Firm-internal factors } \\
\text { - Carbon pricing } \\
\text { - Renewables support } \\
\text { (incl. design features) } \\
\text { - Instrument interaction }\end{array}$ \\
& $\begin{array}{l}\text { - Experience } \\
\text { - Technology portfolio }\end{array}$ \\
\hline
\end{tabular}

Source: Adapted from Rogge and Schleich (2018)

We include both technology-push and demand-pull factors as classical firm-external determinants of innovation (Mowery and Rosenberg, 1979; Di Stefano et al., 2012). In addition, we focus on the influence of multiple instruments and their interaction, thereby following calls for a greater focus on instrument mixes (Cunningham et al., 2013). In doing so, we pay particular attention to instrument design features such as the level of support or its predictability (Hoffmann et al., 2008; Reichardt and Rogge, 2016). It has been suggested that such instrument design features play a key role in driving eco-innovation and in determining instrument interactions (del Río et al., 2016; del Río and Cerdá, 2017).

We focus on the role of firm size, a firm's technology portfolio, and its experience with green technologies as the firm-internal determinants of eco-innovation. In the following, we elaborate on these potential firm-external and firm-internal determinants of eco-innovation, and focus in particular on the role played by the instrument mix.

\subsection{Firm-external determinants of eco-innovation}

Our analytical framework includes technology-push and demand-pull factors as firm-external determinants of eco-innovation (Mowery and Rosenberg, 1979; Di Stefano et al., 2012). In view of the strong relevance of policy for eco-innovation, we focus on policydriven technology push and demand pull (Horbach, 2008). Over the past decade, strong evidence has been accumulated that both aspects matter for eco-innovation (Schmidt et 
Rogge K.S. and Schleich J. (2018): Exploring the Role of Instrument Design and Instrument Interaction for Eco-Innovation: A Survey-Based Analysis of Renewable Energy Innovation in Germany. Chapter 11, pp 233-256, in: Horbach J. and Reif C. (eds): New Developments in Eco-Innovation Research. Sustainability and Innovation. Springer, Cham.

https://doi.org/10.1007/978-3-319-93019-0 11.

al., 2012; Veugelers, 2012; Costantini et al., 2015; Schleich et al., 2017). More specifically, recent evidence has highlighted that demand-pull effects result from a combination of demand at home and abroad, whereas technology-push effects seem to stem from public R\&D support in the domestic market only (Peters et al., 2012; Dechezleprêtre and Glachant, 2014).

While it is often possible to identify technology-push policies by looking at public R\&D funding, it is more challenging to evaluate demand-pull policies (Edler et al., 2012). Therefore, it may be useful to focus on the core demand-pull instruments. In the case of low-carbon innovation, the core demand-pull instrument concerns carbon pricing, for example in the form of an emissions trading systems (Borghesi et al., 2015). The innovation impact of the EU emissions trading system (EU ETS) has been studied extensively, with most findings indicating that it has had a small but positive effect so far (Rogge, 2016). In contrast, studies focusing on innovation in renewable energies include renewables support as the core demand-pull instrument. Del Río and Peñasco (2014) systematically reviewed the empirical literature on national renewable energies support policies, and conclude that feed-in tariffs are the most appropriate promotion instrument to spur innovation and early diffusion in renewable energy sources for electricity generation.

Recent conceptual and empirical work suggests that the innovation effects of policy instruments are not just driven by the type of the instrument, but also and in particular by its design features (Kemp, 1997; Vollebergh, 2007). Perhaps most prominently among these, the relevance of policy stringency has been well established for eco-innovation (Kemp and Pontoglio, 2011; Ghisetti and Pontoni, 2015). However, other design features have also received attention, such as the level of support, the predictability of an instrument, or its flexibility (Hoffmann et al., 2008; Hašcic et al., 2009; Reichardt and Rogge, 2016). For renewable energies, a number of descriptive design features have been suggested for potential consideration, such as the duration of support, decline of support levels over time, quantitative limits for installed capacities (e.g. in GW per year), or technology-specific and geographical differentiation (del Río, 2012; Hoppmann et al., 2013).

In addition, with the introduction of the EU ETS, it has been increasingly argued that the interaction of instruments needs to be taken into consideration when evaluating the impact of climate policy and energy policy (Sorrell and Sijm, 2003; del Río, 2006). Similarly, innovation studies have stressed the need to account for instrument interactions when evaluating innovation policy (Flanagan et al., 2011; Cunningham et al., 2013). So far, however, both lines of research have produced only a few empirical studies with ex-post assessments on the role of such instrument interaction for policy effectiveness (Guerzoni 
and Raiteri, 2015; Cantner et al., 2016). Finally, it has been pointed out that when studying such interaction effects, the design of the interacting instruments should also be considered (del Río, 2010; del Río and Cerdá, 2017). This is consistent with earlier findings on the relevance of design features as one of the determinants of eco-innovation. However, previous empirical ex-post evaluations exploring the role of instrument interactions for eco-innovation have not yet accounted for design features.

Therefore, we are particularly interested in whether instrument design and instrument interaction matter for low-carbon innovation.

\subsection{Firm-internal determinants of eco-innovation}

Regarding the firm-internal determinants of innovation, we draw on insights from evolutionary economics and the resource-based view of the firm (Nelson and Winter, 1982; Wernerfelt, 1984; Barney, 2001). These suggest that a firm's resources, capabilities and competencies matter for innovation, which is why we include three firm characteristics in our analytical framework (Teece et al., 1997; Helfat et al., 2007; del Río et al., 2015).

The first concerns firm size, which has typically been found to affect eco-innovation positively, with larger firms spending more on innovation (Kesidou and Demirel, 2012; del Río et al., 2016).

Second, we include a firm's experience with producing renewable energy technologies in order to capture its accumulated resources as well as its technological and organizational capabilities and competencies in using the respective green technology as determinants of innovation (Kammerer, 2009; Horbach et al., 2012). While others have included a firm's age to capture this effect (del Río et al., 2016), we argue that experience may be the better proxy for this phenomenon for firms which are diversifying their portfolio.

Finally, our framework considers a firm's technology portfolio to control for differences between renewable energy technologies and the relative importance of its green branch, as this may affect a firm's perceptions of and responses to policy stimuli (Schmidt et al., 2012; Huenteler et al., 2016).

\section{$3 \quad$ Research case}

We chose to focus on innovation in renewable energy because decarbonizing the global energy system is expected to involve the massive deployment of renewable energies 
Rogge K.S. and Schleich J. (2018): Exploring the Role of Instrument Design and Instrument Interaction for Eco-Innovation: A Survey-Based Analysis of Renewable Energy Innovation in Germany. Chapter 11, pp 233-256, in: Horbach J. and Reif C. (eds): New Developments in Eco-Innovation Research. Sustainability and Innovation. Springer, Cham.

\section{https://doi.org/10.1007/978-3-319-93019-0 11.}

(IRENA, 2013; IEA and IRENA, 2017). Specifically, we use the case of Germany as a pioneering country for renewables support through feed-in tariffs introduced by the German Renewable Energy Sources Act (EEG) in 2000 and adapted over time in line with socio-technical and socio-political challenges (Grau, 2014; Hoppmann et al., 2014; Lauber and Jacobsson, 2016). As such, the EEG serves as the core renewables instrument within a rich instrument mix which is expected to help Germany meet its national target for the share of renewables in the electricity mix of $40 \%-45 \%$ by 2025 and of at least $80 \%$ by 2050 . In addition, Germany has set itself ambitious short and long-term targets for the reduction of greenhouse gas emissions of $40 \%$ by 2020 and $80 \%$ by 2050 compared to 1990 levels. The EU ETS is typically considered the core climate policy instrument here within a rich instrument mix (Matthes, 2017). This instrument mix, among others, also includes public support for R\&D to facilitate the decarbonization of the energy system. The German government's support here has climbed to above 800 million euros per year since 2014, with a good third of this dedicated to supporting renewable energies (BMWi and BMU, 2010; BMWi, 2015, 2016b).

Several studies have analyzed the German Energiewende in general and core demandpull instruments in particular (Strunz, 2014; Quitzow et al., 2016). However, only a few have looked at instrument interaction and at the role played by instrument design (Lehmann, 2010; Gawel et al., 2014). To the best of our knowledge, no quantitative ex-post evaluation has explicitly addressed the role of instrument design for instrument interaction regarding innovation in renewable energies. Given that innovation in the power sector has traditionally been dominated by suppliers, we focus on the innovation activities of manufacturers of renewable power generation technologies in Germany, because of its strong and export-oriented manufacturing base (Pavitt, 1984; Rogge and Hoffmann, 2010). We rely on survey data as it allows us to capture firm-specific assessments of the instrument mix.

Dedicated company surveys addressing the links between policy and low-carbon innovation in the German energy sector are rare. Two relevant exceptions are the studies of Schmidt et al. (2012) and Doblinger et al. (2015), who surveyed, among others, German manufacturers of renewable power generation technologies in 2009 and 2012, respectively. For non-emitting technologies, i.e. primarily for renewable energy technologies, Schmidt et al. (2012) find that the firms' perceptions of long-term climate targets, technology policies and their expectations about the third phase of the EU ETS are related to their R\&D decisions. Doblinger et al. (2015) conclude that stronger demand-pull policies reduce the realization of high-risk $R \& D$ projects in favor of smaller improvements; a finding that was reinforced by perceived higher levels of regulatory uncertainty. However, 
Rogge K.S. and Schleich J. (2018): Exploring the Role of Instrument Design and Instrument Interaction for Eco-Innovation: A Survey-Based Analysis of Renewable Energy Innovation in Germany. Chapter 11, pp 233-256, in: Horbach J. and Reif C. (eds): New Developments in Eco-Innovation Research. Sustainability and Innovation. Springer, Cham.

https://doi.org/10.1007/978-3-319-93019-0 11.

neither study addresses instrument interactions or uses a conventional innovation survey questionnaire.

The year 2013, i.e. the year before we conducted our survey, was characterized by considerable regulatory uncertainty. Following the Fukushima accident in 2011 and the resulting decision by the German government to phase out nuclear energy by 2022 (Hermwille, 2016), and due to the decline in technology costs, particularly for PV modules (Hoppmann et al., 2014), the share of renewable energies in the German electricity mix grew strongly in 2012 (BMWi, 2015). The subsequent increases in the EEG surcharge led to high-level debates about a retrospective downward adjustment of the guaranteed feed-in tariffs (set for 20 years). Such a retrospective adjustment had previously been unthinkable (Bröcker, 2013). Although, ultimately, no such adjustment was made, its very debate is likely to have tarnished the predictability and associated investment security of the EEG, the core demand-pull instrument. Moreover, in light of the federal elections, which took place in the fall of 2013, the next regular reform of the EEG was postponed until the formation of a new government coalition. This resulted in substantial uncertainty about the ambition of the Energiewende in general and the future of the EEG in particular.

Eventually, the new coalition government subsumed all Energiewende-related activities under one roof at the new Federal Ministry of Economics and Energy (BMWi). In early 2014, the BMWi published the first pillars for the revision of the EEG (BMWi, 2016a). However, the uncertainty about important design features of the new EEG 2.0 remained high until the Federal Cabinet adopted the amended Renewable Energy Sources Act on April 8, 2014.2 Planned design changes included, among others, the reduction of feedin tariffs and the introduction of auctions to determine support levels as an alternative to feed-in tariffs. Further design changes concerned the introduction of technology-specific binding expansion corridors as well as the step-wise expansion of direct marketing and the reduction of privileges for self-consumed power.

Amidst these policy mix developments, the share of renewables in the electricity mix had reached $27.4 \%$ by the end of 2014 , and Germany was on track to meet its 2025 target (BMWi, 2014).

2 This uncertainty was fully resolved after approval was given by the Federal Parliament (Bundestag) on July 4, 2014. 
https://doi.org/10.1007/978-3-319-93019-0 11.

\section{$4 \quad$ Methodology}

Our empirical analysis relies on a novel dataset from a survey of German manufacturers of renewable power generation technologies. We briefly describe the data collection in section Error! Reference source not found., and refer to Rogge and Schleich (2018) for further details, especially on the construction of the company database and the implementation of the survey. Section 4.2 then presents the econometric model and the variables used.

\subsection{Data}

Our data relies on computer-assisted telephone interviews (CATI), which were carried out by the research institute SOKO between April 9, 2014 and July 22, 2014 with 390 CEOs or top-level managers responsible for company strategy, R\&D or sales and with an overview of products, innovation and corporate policy. ${ }^{3}$ On average, these phone interviews lasted for 30 minutes. All data were anonymized by SOKO for further processing.

To a large extent, our questionnaire draws on the Community Innovation Survey (CIS), an established tool for measuring corporate innovation activities in European Member States. Since the CIS includes only few items on policy, we added supplementary questions to the policy mix. 4 Among others, we asked for the respondents' perceptions regarding specific policy instruments including the EU ETS and the EEG. In particular, we also added questions relating to changes to key design features of the EEG as the core demand-pull instrument for renewable energy technologies. The specific questions on design features refer to the amended EEG of April 8, 2014 (see Table 1). 5

3 The 390 participants correspond to a response rate of $35.7 \%$ of all German manufacturers of renewable power generation technologies.

4 In case companies had more than one renewable power generation technology in their portfolio, respondents were asked to answer questions concerning their main renewable power generation technology so as to be able to gather technology-specific information, in particular regarding the instrument mix and innovation expenditures.

5 A more detailed account of the questionnaire is available in Rogge and Schleich (2018). 
Rogge K.S. and Schleich J. (2018): Exploring the Role of Instrument Design and Instrument Interaction for Eco-Innovation: A Survey-Based Analysis of Renewable Energy Innovation in Germany. Chapter 11, pp 233-256, in: Horbach J. and Reif C. (eds): New Developments in Eco-Innovation Research. Sustainability and Innovation. Springer, Cham.

https://doi.org/10.1007/978-3-319-93019-0 11.

Table 1: Operationalization of variables for instrument design features of the EEG

\begin{tabular}{|c|c|c|}
\hline $\begin{array}{l}\text { EEG design } \\
\text { feature }\end{array}$ & $\begin{array}{l}\text { Statement } \\
\text { [own translation from German into English] } \\
\text { In early April, the Federal Cabinet adopted an } \\
\text { Amendment to the Renewable Energy Sources Act. } \\
\text { In your mind, to which extent did changes in the fol- } \\
\text { lowing elements negatively affect sales of your main } \\
\text { renewable power generation technology in Ger- } \\
\text { many.* }\end{array}$ & $\begin{array}{l}\text { Variable } \\
\text { name }\end{array}$ \\
\hline Feed-in tariffs & The lowering of the feed-in tariffs. & Lower_FIT \\
\hline Auctions & The introduction of auctions to elicit support levels. & Auction \\
\hline $\begin{array}{l}\text { Binding expan- } \\
\text { sion corridor }\end{array}$ & $\begin{array}{l}\text { The introduction of technology-specific binding ex- } \\
\text { pansion corridors. }\end{array}$ & Corridor \\
\hline $\begin{array}{l}\text { Mandatory di- } \\
\text { rect marketing }\end{array}$ & $\begin{array}{l}\text { The stepwise introduction of mandatory direct mar- } \\
\text { keting. }\end{array}$ & Market \\
\hline $\begin{array}{l}\text { Self-consumed } \\
\text { power }\end{array}$ & The disadvantaging of self-consumed power. & Self_cons \\
\hline
\end{tabular}

* Response categories ranged from 1 (do not expect negative effects at all) to 6 (expect very negative effects); and "don't know”.

Our sample of 390 responses includes approximately $70 \%$ responses from small and medium-sized enterprises (SMEs). More than half concern solar PV (ca. 37\%); other large shares relate to biogas (ca. 22\%) and onshore wind power (ca. 17\%). The large majority of these produce components for renewable power generation technologies (ca. $71 \%$ ), with the remainder either producing final products for generating power from renewable energy sources (ca. 24\%) or the respective production plants (ca. 5\%). In 2013, only $11.1 \%$ of the companies in our sample operated exclusively in the German market; on average, exports accounted for almost $40 \%$ of sales.

The majority of respondents were fairly active with regard to innovation. More than $80 \%$ of companies had carried out innovation activities in the three years prior to the survey (2011-13). In addition, three out of four companies had introduced product innovations during this period and two-thirds had introduced process innovations for the selected renewable power generation technology. Between 2011 and 2013, about a quarter of 
the respondents had received public R\&D funding (from Germany or the EU) to pursue innovation activities in the main renewable power generation technology.

\subsection{Econometric model}

\subsubsection{Dependent variable}

The econometric analysis follows Rogge and Schleich (2018) in that we use innovation expenditures as the dependent variable in our multivariate analysis. Specifically, we used survey information on actual or estimated innovation expenditures for each company's main renewable power generation technology in 2014 and 2015.6 A substantial portion of the companies reported innovation expenditure of zero in one or both years, i.e. $25.6 \%$ for 2014 and $31.3 \%$ for 2015 . We therefore employ the "corner solution" Tobit model to specify the regression equation for innovation expenditures in a particular year $(y)$. Relying on the "latent variable" approach, truncation (from below) is modeled as:

$$
\text { (1) } \begin{aligned}
& y_{i}^{*}=\beta X_{i}+u_{i} ; \\
& y_{i}=y_{i} * \text { if } y_{i}^{*} \geq 0 \\
& y_{i}=0 \text { if } y_{i}^{*}<0
\end{aligned}
$$

where $y_{i} *$ reflects the latent (i.e. desired) level of innovation expenditures of firm $i$ in a given year. The vector of explanatory variables $X_{i}$ allows us to test our hypotheses and capture other factors related to firms' innovation expenditures. Thus, positive values for innovation expenditures are observed if $\mathrm{y}^{*}$ exceeds the threshold level of zero; otherwise companies report zero expenditures.

Estimating innovation expenditures separately for 2014 and 2015 may lead to biased and inconsistent parameter estimations (Greene, 2012). We therefore estimate a bivariate Tobit model, where the error terms capture possible correlations between innovation expenditures in 2014 and 2015. Simulated maximum likelihood methods as implemented in Stata 14 are used to estimate the model.

6 Respondents were asked about their expenditures for innovation activities (including intramural-in-house-and extramural R\&D, acquisition of machinery, equipment and software, acquisition of other external knowledge, and other preparation). 


\subsubsection{Explanatory variables}

We include five groups of explanatory variables to capture the effects of: (i) technology push and demand pull (TP \& DP), (ii) policy instruments, (iii) EEG design features, (iv) instrument interaction, and $(v)$ control variables to reflect company- and technology-specific effects. Table 2 presents the descriptive statistics for the sample used in the econometric analysis.

(i) Technology push and demand pull

Regarding technology push, we use the amount of public R\&D funding (in euros) each company had received between 2011 and 2013 from German or EU funding bodies for the main technology (TechPush). Most of the companies in our sample had identified Germany $(n=360)$ and Europe $(n=333)$ as their home market.

Regarding demand pull, we relied on a dummy variable (DemandPull), which takes the value of one if the respondent expected the sum of domestic sales and exports of the main technology in 2014 to be higher than in 2013 and zero otherwise. This variable can be interpreted as a proxy for the effect of global demand-pull instruments because of the strong dependence of the market demand for renewable power generation technologies on such instruments (Peters et al., 2012; Hoppmann et al., 2013; Dechezleprêtre and Glachant, 2014).

\section{(ii) Policy instruments}

To specifically capture the effect of the core demand-pull instruments on innovation activities in renewable power technologies, we consider companies' perceptions towards the two core demand-pull instruments EU ETS and EEG.

First, the survey asked participants to evaluate to which extent the EU ETS supports the development of renewable energies. Response categories ranged from 1 (does not support it at all) to 6 (supports very strongly). To construct SupportETS, we first calculate the median value of the responses. Then, SupportETS takes on the value of one if the response category was at least as high as the median value and zero otherwise.

Second, the survey asked participants to evaluate to which extent the EEG supports the development of renewable energies. Response categories again ranged from 1 (does not support it at all) to 6 (supports very strongly). As before, to construct SupportEEG, we first calculate the median value of the responses. Then, SupportEEG takes on the value of one if the response category was at least as high as the median value and zero otherwise. 
(iii) EEG design features

The set of EEG design features include the five variables described in Table 1, i.e. Lower_FIT, Auction, Corridor, Market, and Self_cons. These variables are all constructed in the same way. We first calculate the median value of the responses to the statement presented in Table 2. The variable is then coded as one if the response category was at least as high as the median value and zero otherwise.

(iv) Instrument interaction

To explore possible interaction effects between the EU ETS and the EEG, we focus on the reduced level of support as the key EEG design feature. We chose LowerFIT because this was the most important of the five EEG design features considered according to the descriptive statistics for the original items. Consequently, we constructed ETSXFIT by multiplying SupportETS and Lower_FIT.

(v) Company- and technology-specific factors

We include four variables to control for firm-internal effects. First, size captures the total sales of each firm in 2013 in domestic and foreign markets (i.e. for diversified firms, this includes business fields other than the main renewable energy technology). The second variable, experience, is calculated as the number of years each firm had been offering products for the main renewable power generation technology (using 2014 as the reference year). Finally, we capture each firm's technology portfolio with two explanatory variables: wind takes the value of one if a firm's responses referred to either onshore or offshore wind and zero otherwise7; $R E$ _share measures the share of employees working in the main renewable power generation technology in 2013 relative to all employees.

7 Including dummies for other renewable energy technologies yielded coefficients which were far from being statistically significant. We therefore only incorporate wind. 

teraction for Eco-Innovation: A Survey-Based Analysis of Renewable Energy Innovation in Germany. Chapter 11, pp 233-256, in: Horbach J. and Reif C. (eds): New Developments in Eco-Innovation Research. Sustainability and Innovation. Springer, Cham.

https://doi.org/10.1007/978-3-319-93019-0 11.

Table 2: Descriptive statistics of dependent and explanatory variables $(\mathrm{N}=160)$

\begin{tabular}{|l|l|l|l|l|l|}
\hline Variables & Unit & Mean & $\begin{array}{l}\text { Standard } \\
\text { deviation }\end{array}$ & $\begin{array}{l}\text { Mini- } \\
\text { mum }\end{array}$ & $\begin{array}{l}\text { Maxi- } \\
\text { mum }\end{array}$ \\
\hline $\begin{array}{l}\text { Innovation expenditures } \\
2014^{*}\end{array}$ & in 1,000 euros & 2,115 & 95,600 & 0 & 75,000 \\
\hline $\begin{array}{l}\text { Innovation expenditures } \\
2015^{*}\end{array}$ & in 1,000 euros & 2,308 & 97,471 & 0 & 75,000 \\
\hline TechPush & in 1,000 euros & 130.2 & 651.1 & 0 & 6,000 \\
\hline DemandPull & dummy & 0.36 & 0.481 & 0 & 1 \\
\hline SupportETS & dummy & 0.61 & 0.490 & 0 & 1 \\
\hline SupportEEG & dummy & 0.72 & 0.451 & 0 & 1 \\
\hline Lower_FIT & dummy & 0.575 & 0.496 & 0 & 1 \\
\hline Auction & dummy & 0.669 & 0.472 & 0 & 1 \\
\hline Corridor & dummy & 0.738 & 0.441 & 0 & 1 \\
\hline Market & dummy & 0.519 & 0.501 & 0 & 1 \\
\hline Self_cons & in $\%$ & 0.606 & 0.490 & 0 & 1 \\
\hline ETSxFIT & dummy & 0.338 & 0.474 & 0 & 1 \\
\hline Size (sales)* & dummy & 298.38 & 711.99 & 0.05 & 5,500 \\
\hline Experience* & 15.33 & 11.76 & 0 & 64 \\
\hline Wind & 0.22 & 0.41 & 0 & 1 \\
\hline RE_share & 50.81 & 37.47 & 0.04 & 100 \\
\hline
\end{tabular}

* The natural logarithm is used in the econometric estimation. 8

8 Since the logarithm of zero is not defined, using the logarithm meant losing one observation (where magnitudes were zero). No observation in our final sample had zero experience. When public R\&D (TechPush) or innovation expenditures were zero, we assigned the value of zero to the undefined logarithm. Taking the logarithm did not lead to negative values for the dependent variables, because all positive innovation expenditures in 2014 and 2015 exceeded 1,000 Euros (Note that innovation expenditures are measured in units of $1000 \mathrm{eu}-$ ros). 


\section{$5 \quad$ Results}

Our econometric analysis involves estimating three alternative model specifications. The Base model includes the company- and technology-specific factors together with the technology-push and demand-pull variables. The Instruments \& design model also includes the two core demand-pull instruments EU ETS and EEG and the EEG design features. The Interaction model differs from the Instruments \& design model by the addition of the interaction variable ETSxFIT. Table 3 displays the estimation results and reports heteroskedasticity-robust $p$-values in parentheses below the parameter estimates.

We first note that all three models produce very similar results for the company- and technology-specific factors. We further note that, in all three models, the correlation between the two equations is high and positive and statistically significant, thus corroborating the use of the multivariate Tobit framework. 9 Also, collinearity does not appear to be a problem. 10

\subsection{Base model}

In general, the coefficients in the base model all exhibit the expected signs and are almost all statistically significant. They are also very similar to the respective findings in Rogge and Schleich (2018), although the samples differ slightly between the two studies because of differences in missing observations for the different sets of explanatory variables. To allow for better comparability across the models presented in this study, we limit all analyses to observations where participants responded to the items on the EEG design features. 11

9 For example, for the Base model $\rho=0.902$. Based on a Likelihood-Ratio test, the Null Hypothesis $(\rho=0)$ can be rejected at $p<0.01\left(\chi^{2}(1)=216.801\right)$. Similar conclusions can be drawn for the Instruments \& Design and the Interaction models.

10 When considering all explanatory variables used in the Interaction model, the average variance inflation factor (VIF) is 1.74 and all VIFs of the individual variables are below 4.5 , and thus well below 10, which is the critical threshold value commonly used in the literature.

11 Our findings are virtually the same if we relax this condition. 
Rogge K.S. and Schleich J. (2018): Exploring the Role of Instrument Design and Instrument Interaction for Eco-Innovation: A Survey-Based Analysis of Renewable Energy Innovation in Germany. Chapter 11, pp 233-256, in: Horbach J. and Reif C. (eds): New Developments in Eco-Innovation Research. Sustainability and Innovation. Springer, Cham.

https://doi.org/10.1007/978-3-319-93019-0 11.

More specifically, the findings confirm the positive relationship of European technologypush and global demand-pull effects with innovation expenditures in 2014 and 2015. Calculating the marginal effect for TechPush in the R\&D 2014 equation implies that, on average, a one percent increase in public subsidies for R\&D received for a manufacturer's main renewable power generation technology between 2011 and 2013 is associated with an increase in firm-level innovation expenditures by 0.147 percent in 2014 for firms with positive innovation expenditures in 2014.12.

For our firm characteristics, we find positive and significant correlations with innovation expenditures. As expected, our results show that larger firms (in terms of sales) are positively related to higher innovation expenditures in 2014 and 2015. For example, a onepercent increase in sales is associated with an increase in innovation expenditures of about one percent in both years. More experienced firms (in terms of years of activity in the main renewable power generation technology) spend more on innovation, but the coefficient for 2014 is not statistically significant at conventional levels. Firms active in wind technologies are associated with statistically significantly higher innovation expenditures in 2014 and 2015 compared with firms that focus on other renewable electricity technologies, indicating strong differences across technologies. Finally, the coefficient associated with the share of employees working in the main renewable power generation technology takes on the expected positive sign, and turns out to be significant for both 2014 and 2015.

\subsection{Instruments \& design model}

Regarding our variables for the two core demand-pull instruments, SupportETS and SupportEEG, we found no support for a correlation with innovation expenditures for either year.

The results for the Instruments \& design model suggest that three of the five EEG design features, i.e. Lower_FIT, Market and Auction, are statistically significantly related with innovation expenditures for both years. First, a perceived negative effect of lowering the feed-in tariffs on manufacturers' sales of renewable energy technologies is negatively related to innovation expenditures in 2014 and 2015. Second, perceiving the stepwise introduction of mandatory direct marketing to have negative effects on sales is negatively

12 Consistent marginal effects were derived from running a single Tobit model for innovation expenditures in 2014. 
associated with innovation expenditures in both years. Finally, auction and thus the policy design change to determine the level of support through auctions rather than predetermining it through feed-in tariffs turned out to be statistically significant for innovation expenditures in 2015, while the coefficient for 2014 is just shy of being statistically significant.

In comparison, the coefficients associated with Corridor, and Self_cons were far from being statistically significant for both years.

Finally, we note that our technology-push variable no longer exhibits statistical significance at conventional levels, most likely because of the lower degrees of freedom in the Instrument \& design model compared to the Base model.

\subsection{Interaction model}

Our final model explores the potential effects of interaction between our two core demand-pull policy instruments. Specifically, we consider the interaction between the EU ETS as the most important EU climate policy instrument and the reduced feed-in tariffs as the main EEG design feature. Since the findings for the other explanatory variables in the Interaction model are almost identical to those of the Instruments \& design model, we focus on the findings for this interaction term. The positive and statistically significant coefficient associated with ETSXFIT suggests that the positive effect of the EU ETS on innovation expenditures is stronger, the more negative the perceived effects of lowering the FITs are on sales. By the same token, strong negative perceived effects of lowering the FITs are stronger, the less positive the perceived effects of the EU ETS are on sales. 
Rogge K.S. and Schleich J. (2018): Exploring the Role of Instrument Design and Instrument Interaction for Eco-Innovation: A Survey-Based Analysis of Renewable Energy Innovation in Germany. Chapter 11, pp 233-256, in: Horbach J. and Reif C. (eds): New Developments in Eco-Innovation Research. Sustainability and Innovation. Springer, Cham.

https://doi.org/10.1007/978-3-319-93019-0 11.

Table 3: Regression results

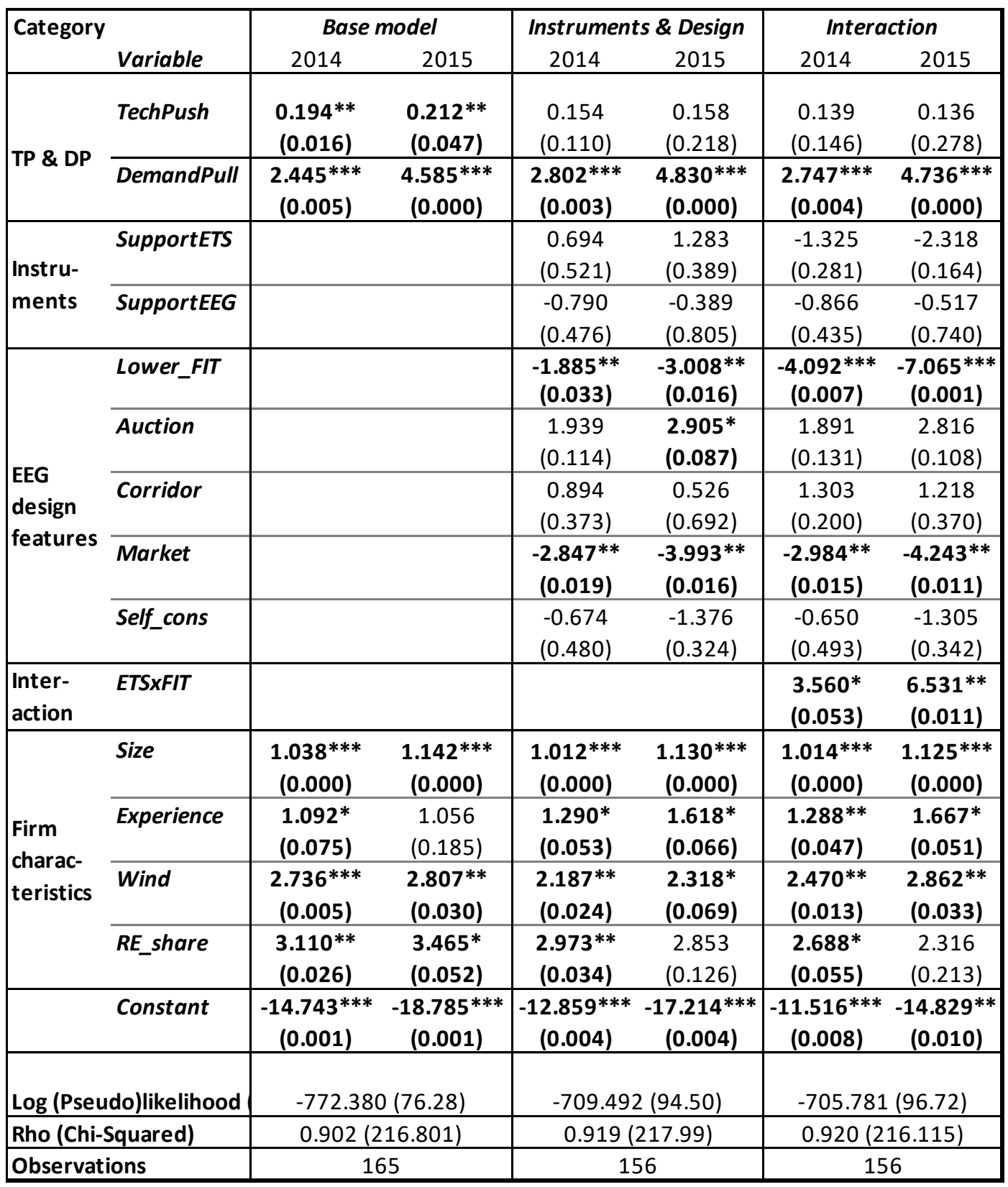

Note: Robust $p$-values in parentheses; ${ }^{* * *} p<0.01,{ }^{* *} p<0.05,{ }^{*} p<0.1$

\section{$6 \quad$ Discussion and conclusions}

Bearing in mind the explorative nature of our study, our econometric analysis provides evidence that changes in instrument design and instrument interaction matter for eco- 
Rogge K.S. and Schleich J. (2018): Exploring the Role of Instrument Design and Instrument Interaction for Eco-Innovation: A Survey-Based Analysis of Renewable Energy Innovation in Germany. Chapter 11, pp 233-256, in: Horbach J. and Reif C. (eds): New Developments in Eco-Innovation Research. Sustainability and Innovation. Springer, Cham.

https://doi.org/10.1007/978-3-319-93019-0 11.

innovation in the case of renewable power generation technologies in Germany. In particular, if companies believe a change in certain EEG design features (such as lowering the feed-in-tariff, introducing auctions, or mandatory direct marketing) will negatively affect their domestic sales, they are likely to spend less on low-carbon innovation. In addition, when considering the interaction between the EU ETS and the most relevant design feature of the EEG (the feed-in tariffs), we find that favorable perceptions about the impact of the EU ETS on innovation have a stronger positive effect on innovation expenditures, the more negative the perceived effects of lowering the FIT are on sales. In contrast, we find no correlation between innovation and these perceived effects of the EU ETS and EEG per se.

These results confirm earlier findings in the literature suggesting that instrument design rather than instrument type matter for eco-innovations (Kemp and Pontoglio, 2011). In addition, our study confirms theoretical considerations concerning the importance of accounting for design features of policy instruments when investigating their interactions (del Río and Cerdá, 2017). That is, we find that both policy instrument design and interaction matter for innovation in renewable energies, and thus should be considered in future studies on the links between policy and eco-innovation.

Turning to technology push, we find that public financial support for innovation projects is linked with higher private innovation expenditures in the future, which is generally in line with the literature (Johnstone et al., 2010; Costantini et al., 2015).

Regarding demand-pull effects, our study supports earlier findings that market growthwhich in the case of renewable energies at the time of our survey was still mainly policyinduced-is positively associated with eco-innovation (Horbach, 2008; Hoppmann et al., 2013; Schleich et al., 2017). In our case, technology providers who expect their sales of green technologies to increase compared with the previous year tend to spend more on low-carbon innovation. Of course, this growth expectation not only depends on policyinduced market growth, but also on the competiveness of firms. For example, in recent years, PV module manufacturers in Germany have been particularly challenged by Chinese competitors (Quitzow, 2015). Ultimately, global and not only domestic market expectations matter.

In terms of our control variables, we find strong evidence that firm size (measured in total sales in 2013) positively affects low-carbon innovation expenditures. These results are in line with others reported in the eco-innovation literature (Kammerer, 2009; Kesidou and Demirel, 2012; del Río et al., 2016). In addition, we also find evidence that experi- 
Rogge K.S. and Schleich J. (2018): Exploring the Role of Instrument Design and Instrument Interaction for Eco-Innovation: A Survey-Based Analysis of Renewable Energy Innovation in Germany. Chapter 11, pp 233-256, in: Horbach J. and Reif C. (eds): New Developments in Eco-Innovation Research. Sustainability and Innovation. Springer, Cham.

https://doi.org/10.1007/978-3-319-93019-0 11.

ence with the main renewable power generation technology (measured in years) positively correlates with innovation expenditures for renewable power generation technologies, suggesting that early movers spend more on green innovation. This also underlines the importance of technological and organizational capabilities found in the eco-innovation literature (Kammerer, 2009; Demirel and Kesidou, 2011; Horbach et al., 2012). Regarding the technology portfolio, our findings suggest possible differences across technologies (Huenteler et al., 2016), with those companies active in on- and offshore wind power committing to higher innovation expenditures than the rest. Furthermore, firms with a higher share of employees working in the main renewable power generation technology were found to spend more on innovation in renewable power generation technologies.

Overall, we argue that our explorative study provides empirical support for going beyond aggregated technology-push and demand-pull variables in studies examining the links between policy and eco-innovation, and extending policy coverage to include the design of core policy instruments, and instrument interaction. In particular, we find strong evidence for a positive relationship between innovation expenditures on renewable power technologies and changes in design features, where negative expectations regarding the potential effect on sales are associated with lower innovation expenditures. We also find that the interaction effects of instruments may be driven by specific design features of core policy instruments.

Clearly, this novel empirical research is not free of limitations, and should be seen as a first step to analyzing the impact of instrument mixes on eco-innovation. First, choosing the German Energiewende for such an exploratory study makes it possible to draw lessons from one of the most advanced cases of low-carbon transition. The focus on one country and one sector obviously implies that our results may not be readily transferable to other contexts. Second, while operationalizing instrument design features proved feasible within an innovation survey, and the correlations found between innovation and the policy variables build upon and support earlier qualitative findings, we also recognize the caveats inherent to survey-based research such as recall bias, social desirability bias and common method bias. In particular, cross-sectional analyses are limited to correlations rather than causal inference. Third, our operationalization of the measurement of perceptions of the instrument mix should be regarded as a first attempt only.

Our exploratory empirical study on how instrument design and instrument interaction affect eco-innovation also suggests areas for future research (see also Rogge and Schleich, 2018). Future empirical research on the impact of instrument mixes and ecoinnovation could try to establish causality rather than correlations. Specifically, a periodic 
innovation survey among low-carbon technology manufacturers could eventually allow panel analyses. Such a survey could take a broader systems perspective and also cover providers of complementary or enabling technologies, such as storage or grid technologies. These surveys could also be implemented across several countries, thus providing for a better understanding of policy mix aspects such as the relevance of instrument design and interaction. For example, additional insights into the links between policy and low-carbon innovation could be generated by comparing findings for countries with a similar industry structure but alternative governance approaches regarding the transition of the energy system. Finally, if the CIS or similar surveys included policy mix questions enabling cross-sectoral comparisons, it would be possible to assess the role of instrument mixes for eco-innovation in the more general greening of the economy.

Ultimately, we hope the findings of our explorative study will initiate a critical assessment of how policy and eco-innovation are measured in innovation surveys and beyond. Clearly, further research is needed to help establish new standards in innovation surveys and in the analysis of policy instruments' interactions.

\section{Acknowledgements}

This chapter was written in the context of Fraunhofer ISI's internal project TransPoSi, which investigates transformative policy processes for system innovation, and the corresponding role of visions, targets and instruments. The data underlying our analysis was

collected as part of the GRETCHEN project (2012-15), funded by the Federal Ministry of Education and Research (BMBF) within its FONA funding initiative "Economics of Climate Change" (Econ-C-026).

\section{$7 \quad$ References}

Barney, J., 2001. Resource-based theories of competitive advantage: A ten-year retrospective on the resource-based view. Journal of Management 27 (6), 643-650. 10.1016/S0149-2063(01)00115-5.

Bergek, A., Berggren, C., 2014. The impact of environmental policy instruments on innovation: A review of energy and automotive industry studies. Ecological Economics 106, 112-123. 10.1016/j.ecolecon.2014.07.016.

BMWi, 2014. Act on the Development of Renewable Energy Sources (Renewable Energy Sources Act - RES Act 2014): EEG. 
BMWi, 2015. The Energy of the Future - Fourth "Energy Transition" Monitoring Report Summary: A good piece of work. Federal Ministry for Economic Affairs and Energy, Berlin.

BMWi, 2016a. 10-point agenda: A clear roadmap for the energy transition. Federal Ministry for Economic Affairs and Energy.

http://www.bmwi.de/Redaktion/EN/Dossier/energy-transition.html. Accessed 27 June 2017.

BMWi, 2016b. Bundesbericht Energieforschung 2016: Forschungsförderung für die Energiewende. Federal Ministry for Economic Affairs and Energy, Berlin.

BMWi, BMU, 2010. Energy Concept for an Environmentally Sound, Reliable and Affordable Energy Supply. Federal Ministry of Economics and Technology, Federal Ministry for the Environment, Berlin.

Borghesi, S., Cainelli, G., Mazzanti, M., 2015. Linking emission trading to environmental innovation: Evidence from the Italian manufacturing industry. Research Policy 44 (3), 669-683. 10.1016/j.respol.2014.10.014.

Bröcker, M., 2013. Regierung plant Bremse für den Strompreis. Rheinische Post 2013.

Bruns, E., Ohlhorst, D., Wenzel, B., Köppel, J., 2011. Renewable Energies in Germany's Electricity Market: A Biography of the Innovation Process. Springer Netherlands, Dordrecht.

Cantner, U., Graf, H., Herrmann, J., Kalthaus, M., 2016. Inventor networks in renewable energies: The influence of the policy mix in Germany. Research Policy 45 (6), 1165-1184. 10.1016/j.respol.2016.03.005.

Costantini, V., Crespi, F., Martini, C., Pennacchio, L., 2015. Demand-pull and technology-push public support for eco-innovation: The case of the biofuels sector. Research Policy 44 (3), 577-595. 10.1016/j.respol.2014.12.011.

Cunningham, P., Edler, J., Flanagan, K., Laredo, P., 2013. Innovation policy mix and instrument interaction: a review. Nesta Working Paper Series 13/20. NESTA, 47 pp. www.nesta.org.uk/wp13-20.

Dechezleprêtre, A., Glachant, M., 2014. Does Foreign Environmental Policy Influence Domestic Innovation?: Evidence from the Wind Industry. Environ Resource Econ 58 (3), 391-413. 10.1007/s10640-013-9705-4. 
del Río, P., 2006. The interaction between emissions trading and renewable electricity support schemes: An overview of the literature. Mitig Adapt Strat Glob Change 12 (6), 1363-1390.

del Río, P., 2009. The empirical analysis of the determinants for environmental technological change: A research agenda. Ecological Economics 68 (3), 861-878.

10.1016/j.ecolecon.2008.07.004.

del Río, P., 2010. Analysing the interactions between renewable energy promotion and energy efficiency support schemes: The impact of different instruments and design elements. Energy Policy 38 (9), 4978-4989. 10.1016/j.enpol.2010.04.003.

del Río, P., 2012. The dynamic efficiency of feed-in tariffs: The impact of different design elements. Energy Policy 41, 139-151. 10.1016/j.enpol.2011.08.029.

del Río, P., Carrillo-Hermosilla, J., Könnölä, T., Bleda, M., 2015. Resources, capabilities and competences for eco-innovation. Technological and Economic Development of Economy 22 (2), 274-292. 10.3846/20294913.2015.1070301.

del Río, P., Cerdá, E., 2017. The missing link: The influence of instruments and design features on the interactions between climate and renewable electricity policies. Energy Research \& Social Science 33, 49-58. 10.1016/j.erss.2017.09.010.

del Río, P., Peñasco, C., 2014. Innovation Effects of Support Schemes for Renewable Electricity. Universal Journal of Renewable Energy 2, 45-66.

del Río, P., Peñasco, C., Romero-Jordán, D., 2016. What drives eco-innovators?: A critical review of the empirical literature based on econometric methods. Journal of Cleaner Production 112, 2158-2170. 10.1016/j.jclepro.2015.09.009.

Demirel, P., Kesidou, E., 2011. Stimulating different types of eco-innovation in the UK: Government policies and firm motivations. Ecological Economics 70 (8), 15461557. 10.1016/j.ecolecon.2011.03.019.

Di Stefano, G., Gambardella, A., Verona, G., 2012. Technology push and demand pull perspectives in innovation studies: Current findings and future research directions. Research Policy 41 (8), 1283-1295. 10.1016/j.respol.2012.03.021.

Doblinger, C., Dowling, M., Helm, R., 2015. An institutional perspective of public policy and network effects in the renewable energy industry: Enablers or disablers of entrepreneurial behaviour and innovation? Entrepreneurship \& Regional Development 28 (1-2), 126-156. 10.1080/08985626.2015.1109004. 
Edler, J., Georghiou, L., Blind, K., Uyarra, E., 2012. Evaluating the demand side: New challenges for evaluation. Research Evaluation 21 (1), 33-47. 10.1093/rese$\mathrm{val} / \mathrm{rvr002}$.

Flanagan, K., Uyarra, E., Laranja, M., 2011. Reconceptualising the 'policy mix' for innovation. Research Policy 40 (5), 702-713. 10.1016/j.respol.2011.02.005.

Frondel, M., Horbach, J., Rennings, K., 2008. What triggers environmental management and innovation? Empirical evidence for Germany. Ecological Economics 66 (1), 153-160. 10.1016/j.ecolecon.2007.08.016.

Gallagher, K.S., Grübler, A., Kuhl, L., Nemet, G., Wilson, C., 2012. The Energy Technology Innovation System. Annu. Rev. Environ. Resour. 37 (1), 137-162. 10.1146/annurev-environ-060311-133915.

Gawel, E., Strunz, S., Lehmann, P., 2014. A public choice view on the climate and energy policy mix in the EU - How do the emissions trading scheme and support for renewable energies interact? Energy Policy 64, 175-182. 10.1016/j.enpol.2013.09.008.

Ghisetti, C., Pontoni, F., 2015. Investigating policy and R\&D effects on environmental innovation: A meta-analysis. Ecological Economics 118, 57-66.

10.1016/j.ecolecon.2015.07.009.

Grau, T., 2014. Responsive feed-in tariff adjustment to dynamic technology development. Energy Economics 44, 36-46. 10.1016/j.eneco.2014.03.015.

Greene, W.H., 2012. Econometric analysis. Pearson, Boston, London.

Guerzoni, M., Raiteri, E., 2015. Demand-side vs. supply-side technology policies: Hidden treatment and new empirical evidence on the policy mix. Research Policy 44 (3), 726-747. 10.1016/j.respol.2014.10.009.

Hašcic, I., Johnstone, N., Kalamova, M., 2009. Environmental Policy Flexibility, Search and Innovation. Finance a Uver - Czech Journal of Economics and Finance 59 (5), $426-441$.

Helfat, C.E., Finkelstein, S., Mitchell, W., Peteraf, M.A., Singh, H., 2007. Dynamic capabilities: Understanding strategic change in organizations. Blackwell Publications, Oxford, Cambridge. 
Hermwille, L., 2016. The role of narratives in socio-technical transitions-Fukushima and the energy regimes of Japan, Germany, and the United Kingdom. Energy Research \& Social Science 11, 237-246. 10.1016/j.erss.2015.11.001.

Hoffmann, V.H., Trautmann, T., Schneider, M., 2008. A taxonomy for regulatory uncertainty-application to the European Emission Trading Scheme. Environmental Science \& Policy 11 (8), 712-722.

Hoppmann, J., Huenteler, J., Girod, B., 2014. Compulsive policy-making-The evolution of the German feed-in tariff system for solar photovoltaic power. Research Policy 43 (8), 1422-1441. 10.1016/j.respol.2014.01.014.

Hoppmann, J., Peters, M., Schneider, M., Hoffmann, V.H., 2013. The two faces of market support-How deployment policies affect technological exploration and exploitation in the solar photovoltaic industry. Research Policy 42 (4), 989-1003. 10.1016/j.respol.2013.01.002.

Horbach, J., 2008. Determinants of environmental innovation-New evidence from German panel data sources. Research Policy 37 (1), 163-173. 10.1016/j.respol.2007.08.006.

Horbach, J., Oltra, V., Belin, J., 2013. Determinants and Specificities of Eco-Innovations Compared to Other Innovations-An Econometric Analysis for the French and German Industry Based on the Community Innovation Survey. Industry and Innovation 20 (6), 523-543. 10.1080/13662716.2013.833375.

Horbach, J., Rammer, C., Rennings, K., 2012. Determinants of eco-innovations by type of environmental impact - The role of regulatory push/pull, technology push and market pull. Ecological Economics 78, 112-122. 10.1016/j.ecolecon.2012.04.005.

Huenteler, J., Schmidt, T.S., Ossenbrink, J., Hoffmann, V.H., 2016. Technology life-cycles in the energy sector - Technological characteristics and the role of deployment for innovation. Technological Forecasting \& Social Change 104, 102-121. 10.1016/j.techfore.2015.09.022.

IEA, 2011. Interactions of Policies for Renewable Energy and Climate, Paris.

IEA, IRENA, 2017. Perspectives for the Energy Transition: Investment Needs for a Low-Carbon Energy System. International Energy Agency; International Renewable Energy Agency, Paris, Bonn. 
IRENA, 2013. Renewable Energy Innovation Policy: Success Criteria and Strategies. International Renewable Energy Agency, Bonn.

Jacobsson, S., Bergek, A., 2004. Transforming the energy sector: The evolution of technological systems in renewable energy technology. Industrial and Corporate Change 13 (5), 815-849. 10.1093/icc/dth032.

Jaffe, A.B., Newell, R.G., Stavins, R.N., 2002. Environmental policy and technological change. Environmental \& Resource Economics 22 (1-2), 41-69.

Johnstone, N. (Ed.), 2007. Environmental Policy and Corporate Behaviour. Elgar; OECD, Cheltenham, Paris.

Johnstone, N., Haščič, I., Popp, D., 2010. Renewable Energy Policies and Technological Innovation: Evidence Based on Patent Counts. Environ Resource Econ 45 (1), 133-155. 10.1007/s10640-009-9309-1.

Kammerer, D., 2009. The effects of customer benefit and regulation on environmental product innovation. Ecological Economics 68 (8-9), 2285-2295.

10.1016/j.ecolecon.2009.02.016.

Kemp, R., Pearson, P., 2007. MEI D15 - Final report MEI project about measuring ecoinnovation: Deliverable 15. UM-MERIT, Maastricht.

Kemp, R., Pontoglio, S., 2011. The innovation effects of environmental policy instruments - A typical case of the blind men and the elephant? Ecological Economics 72, 28-36. 10.1016/j.ecolecon.2011.09.014.

Kemp, R.,, 1997. Environmental Policy and Technical Change. Edward Elgar, Cheltenham, Brookfield.

Kesidou, E., Demirel, P., 2012. On the drivers of eco-innovations: Empirical evidence from the UK. Research Policy 41 (5), 862-870. 10.1016/j.respol.2012.01.005.

Lauber, V., Jacobsson, S., 2016. The politics and economics of constructing, contesting and restricting socio-political space for renewables - The German Renewable Energy Act. Environmental Innovation and Societal Transitions 18, 147-163. 10.1016/j.eist.2015.06.005.

Lehmann, P., 2010. Using a policy mix to combat climate change - An economic evaluation of policies in the German electricity sector, $\mathrm{PhD}$ thesis. Universität Halle-Wittenberg. 
Matthes, F.C., 2017. Energy transition in Germany: A case study on a policy-driven structural change of the energy system. Evolut Inst Econ Rev 14 (1), 141-169. 10.1007/s40844-016-0066-x.

Mowery, D., Rosenberg, N., 1979. The influence of market demand upon innovation: a critical review of some recent empirical studies. Research Policy 8 (2), 102-153.

Nelson, R.R., Winter, S.G., 1982. An Evolutionary Theory of Economic Change. Belknapp Press of Harvard University Press, Cambridge.

OECD, 2005. Oslo Manual: Guidelines for collecting and interpreting innovation data. 3rd edition, Paris.

OECD, 2009. Eco-Innovation in Industry - Enabling Green Growth, Paris.

OECD, 2011. Better Policies to Support Eco-innovation. OECD Studies on Environmental Innovation, Paris.

OECD, 2015. System Innovation: Synthesis Report, Paris.

OECD/IEA/NEA/ITF, 2015. Aligning Policies for a Low-carbon Economy. OECD, Paris, $242 \mathrm{pp}$.

Pavitt, K., 1984. Sectoral patterns of technical change: Towards a taxonomy and a theory. Research Policy 13 (6), 343-373. 10.1016/0048-7333(84)90018-0.

Pegels, A., Lütkenhorst, W., 2014. Is Germany's energy transition a case of successful green industrial policy? Contrasting wind and solar PV. Energy Policy 74, 522-534. 10.1016/j.enpol.2014.06.031.

Peters, M., Schneider, M., Griesshaber, T., Hoffmann, V.H., 2012. The impact of technology-push and demand-pull policies on technical change - Does the locus of policies matter? Research Policy 41 (8), 1296-1308. 10.1016/j.respol.2012.02.004.

Quitzow, L., Canzler, W., Grundmann, P., Leibenath, M., Moss, T., Rave, T., 2016. The German Energiewende - What's happening? Introducing the special issue. Utilities Policy 41, 163-171. 10.1016/j.jup.2016.03.002.

Quitzow, R., 2015. Dynamics of a policy-driven market: The co-evolution of technological innovation systems for solar photovoltaics in China and Germany. Environmental Innovation and Societal Transitions 17, 126-148. 10.1016/j.eist.2014.12.002. 
Reichardt, K., Rogge, K., 2016. How the policy mix impacts innovation: Findings from company case studies on offshore wind in Germany. Environmental Innovation and Societal Transitions 18, 62-81. 10.1016/j.eist.2015.08.001.

Rennings, K., 2000. Redefining innovation - eco-innovation research and the contribution from ecological economics. Ecological Economics 32 (2), 319-332. 10.1016/S0921-8009(99)00112-3.

Rennings, K., Rammer, C., 2011. The Impact of Regulation-Driven Environmental Innovation on Innovation Success and Firm Performance. Industry and Innovation 18 (3), 255-283. 10.1080/13662716.2011.561027.

Rogge, K.S., 2016. Reviewing the evidence on the innovation impact of the EU Emission Trading System, in: Weishaar, S. (Ed.), Research Handbook on Emissions Trading. Edward Elgar Publishing, pp. 161-194.

Rogge, K.S., Hoffmann, V.H., 2010. The impact of the EU ETS on the sectoral innovation system for power generation technologies. Energy Policy 38 (12), 7639-7652. 10.1016/j.enpol.2010.07.047.

Rogge, K.S., Kern, F., Howlett, M., 2017. Conceptual and empirical advances in analysing policy mixes for energy transitions. Energy Research \& Social Science 33, $1-$ 10. 10.1016/j.erss.2017.09.025.

Rogge, K.S., Reichardt, K., 2016. Policy mixes for sustainability transitions: An extended concept and framework for analysis. Research Policy 45 (8), 1620-1635. 10.1016/j.respol.2016.04.004.

Rogge, K.S., Schleich, J., 2017. Do policy mix characteristics matter for low-carbon innovation? A survey-based exploration for renewable power generation technologies in Germany. SPRU Working Paper Series (SWPS) 19. University of Sussex, Brighton.

Rogge, K.S., Schleich, J., 2018. Do policy mix characteristics matter for low-carbon innovation? A survey-based exploration of renewable power generation technologies in Germany. Research Policy forthcoming.

Schleich, J., Walz, R., Ragwitz, M., 2017. Effects of policies on patenting in wind-power technologies. Energy Policy 108, 684-695. 10.1016/j.enpol.2017.06.043.

Schmidt, T.S., Schneider, M., Rogge, K.S., Schuetz, M.J.A., Hoffmann, V.H., 2012. The effects of climate policy on the rate and direction of innovation: A survey of the 
EU ETS and the electricity sector. Environmental Innovation and Societal Transitions 2, 23-48. 10.1016/j.eist.2011.12.002.

Sorrell, S., Sijm, J., 2003. Carbon trading in the policy mix. Oxford Review of Economic Policy 19 (3), 420-437.

Spyridaki, N.-A., Flamos, A., 2014. A paper trail of evaluation approaches to energy and climate policy interactions. Renewable and Sustainable Energy Reviews 40, 1090-1107. 10.1016/j.rser.2014.08.001.

Strunz, S., 2014. The German energy transition as a regime shift. Ecological Economics 100, 150-158. 10.1016/j.ecolecon.2014.01.019.

Taylor, M., 2008. Beyond technology-push and demand-pull: Lessons from California's solar policy. Energy Economics 30 (6), 2829-2854. 10.1016/j.eneco.2008.06.004.

Teece, D.J., Pisano, G., Shuen, A., 1997. Dynamic capabilities and strategic management. Strat. Mgmt. J. 18 (7), 509-533. 10.1002/(SICl)10970266(199708)18:7<509:AID-SMJ882>3.0.CO;2-Z.

Veugelers, R., 2012. Which policy instruments to induce clean innovating? Research Policy 41 (10), 1770-1778. 10.1016/j.respol.2012.06.012.

Vollebergh, H., 2007. Impacts of Environmental Policy Instruments on Technological Change. OECD, 34 pp. Accessed 29 June 2014.

Weber, K.M., Rohracher, H., 2012. Legitimizing research, technology and innovation policies for transformative change: Combining insights from innovation systems and multi-level perspective in a comprehensive 'failures' framework. Research Policy 41 (6), 1037-1047. 10.1016/j.respol.2011.10.015.

Wernerfelt, B., 1984. A Resource-Based View Of The Firm. Strateg.Manage.J. 5 (2), 171-180.

Wieczorek, A.J., Hekkert, M.P., 2012. Systemic instruments for systemic innovation problems: A framework for policy makers and innovation scholars. Science and Public Policy 39 (1), 74-87. 10.1093/scipol/scr008. 